\title{
Fuel Cell Membrane Electrode Assemblies Fabricated by Layer-by-Layer Electrostatic Self-Assembly Techniques**
}

\author{
By André D. Taylor, * Marc Michel, Ryan C. Sekol, Jeremy M. Kizuka, Nicholas A. Kotov, and Levi T. Thompson
}

High activity, carbon supported Pt electrocatalysts were synthesized using a supercritical fluid method and a selective heterogeneous nucleation reaction to disperse $\mathrm{Pt}$ onto single walled carbon nanotube and carbon fiber supports. These nanocomposite materials were then incorporated into catalyst and gas diffusion layers consisting of polyelectrolytes, i.e., Nafion, polyaniline, and polyethyleneimine using layer-by-layer (LBL) assembly techniques. Due to the ultrathin nature and excellent homogeneity characteristics of LBL materials, the LBL nanocomposite catalyst layers (LNCLs) yielded much higher Pt utilizations, $3,198 \mathrm{~mW} \mathrm{mg}_{\mathrm{Pt}^{-1}}$, than membrane electrode assemblies produced using conventional methods $\left(\sim 800 \mathrm{~mW} \mathrm{mg}_{\mathrm{Pt}^{-1}}{ }^{-1}\right.$. Thinner membranes (100 bilayers) can further improve the performance of the LNCLs and these layers can function as catalyzed gas diffusion layers for the anode and cathode of a polymer electrolyte membrane fuel cell.

\section{Introduction}

Polymer electrolyte membrane (PEM) fuel cells are being considered for a number of commercial and military applications including use in portable electronic devices, automobiles, and ships. ${ }^{[1-4]}$ One of the key challenges facing the widespread use and commercialization of PEM fuel cells is their high cost. The cost is largely associated with expensive electrocatalytic and membrane materials, and inefficiencies in their utilization. ${ }^{[5]}$ For example, in a conventionally prepared membrane electrode assembly (MEA) only about $10 \%$ of the available $\mathrm{Pt}$ in the electrocatalyst layers is accessible. ${ }^{[6]}$ Another challenge is that the triple phase boundary (TPB) regions must balance the ionic and electronic conduction mediums. These mediums influence the hydrophilic and hydrophobic properties of the composite material and create a design challenge at the nanometer scale of integrating disparate materials.

Based on a recent review by Wee et al., the most common and traditional approach to increasing Pt utilization has involved thin film deposition methods such as sputtering. ${ }^{[7]}$ For example, Hirano et al. deposited a ( $1 \mu \mathrm{m}$ thick) Pt thin film onto an uncatalyzed (i.e., without $\mathrm{Pt}$ ) gas diffusion layer (GDL) with a cathode Pt loading of $0.1 \mathrm{mg}_{\mathrm{Pt}} \mathrm{cm}^{-2}$ and standard E-TEK anode. ${ }^{[8]}$ Although the cathode overpotential at high

[*] Prof. A. D. Taylor, R. C. Sekol Department of Chemical Engineering, Yale University P.O. Box 208286, New Haven, CT 06520-8286 (USA) E-mail: andrew.taylor@yale.edu

Dr. M. Michel, J. M. Kizuka, Prof. N. A. Kotov, Prof. L. T. Thompson Department of Chemical Engineering, The University of Michigan, 3074 H.H. Dow Building

2300 Hayward St., Ann Arbor, MI 48109 (USA)

[**] We acknowledge the UM OVPR office for a faculty seed grant awarded to the first author. We also thank Professor Phillip Savage for generous use of lab space and equipment. current density was reduced, the fuel cell performance was not as good as a standard E-TEK electrode (with a conventional catalyst), presumably due to hindered water transport in the $\mathrm{Pt}$ sputtered layer. O'Hayre et al. adapted this approach by sputtering Pt $\left(0.04 \mathrm{mg}_{\mathrm{Pt}} \mathrm{cm}^{-2}\right)$ directly onto the surface of a Nafion 117 membrane. ${ }^{[9]}$ The Pt utilization, a parameter obtained by dividing the peak power density by the loading, was $826 \mathrm{~mW} \mathrm{mg}_{\mathrm{Pt}}{ }^{-1}$ and it was reported that the performance for this MEA was very sensitive to the thickness of the sputtered Pt layer. ${ }^{[9]}$ Recently, we demonstrated that higher Pt utilizations $\left(15,375 \mathrm{~mW} \mathrm{mg}_{\mathrm{Pt}^{-1}}{ }^{-1}\right)$ can be obtained using nanoimprint lithography to create thin film catalyst materials directly onto Nafion. ${ }^{[10]}$

Due to mass transport limitations and low surface areas of sputtered films significant work has been carried out to determine the best ink formulations for carbon supported $\mathrm{Pt}^{[11-14]}$ For instance, Xiong et al. used a modified thin-film method mixing $\mathrm{Pt} / \mathrm{C}$ with Nafion solution and water to produce films with a Pt loading of $0.1 \mathrm{mg} \mathrm{cm}^{-2}$ and a peak power density of $714 \mathrm{~mW} \mathrm{~cm}^{-2}$. [15] This method yielded a Pt utilization of $7,140 \mathrm{~mW} \mathrm{mg}_{\mathrm{Pt}^{-1}}{ }^{-1}$ and it was further reported that the performance was not severely compromised at Pt loadings as low as $0.05 \mathrm{mg} \mathrm{cm}^{-2}$. Recently, we have also shown high $\mathrm{Pt}$ utilizations $\left(17,600 \mathrm{~mW} \mathrm{mg}_{\mathrm{Pt}}{ }^{-1}\right)$ using inkjet printing technology to construct $3 \mathrm{D}$ catalyst layers. ${ }^{[16]}$ The high precision of inkjet printing technology allows controlled catalyst deposition and we have demonstrated $\mathrm{Pt}$ loadings as low as $0.021 \mathrm{mg}_{\mathrm{Pt}}$ $\mathrm{cm}^{-2}$ (from four deposition passes). Both examples used carbon black (CB) as the Pt support, however many of the Pt particles are either trapped in the pores of the carbon electrodes or isolated (along with the CB particle) away from the TPB region. ${ }^{[17,18]}$

Recently, there has been a growing trend to use nanostructured materials such as carbon nanotubes and carbon fibers $(\mathrm{CFs})$ as fuel cell materials. ${ }^{[19-23]}$ Although these 1D carbons 
possess desirable material properties (i.e., electrical conductivity, thermal, inertness etc.), functionalization ${ }^{[19]}$ and integration ${ }^{[20]}$ challenges remain. As these materials are proven for varous applications, we expect the economies of scale to lower the cost. For example, Hata et al. recently described highly efficient synthesis of impurity-free single walled carbon nanotubes. ${ }^{[24]}$

Tang et al. demonstrated an advantage of nanostructured materials by using freestanding Pt/SWCNTs mats (created using a dissolved filter technique) on the cathode side of a PEM fuel cell. ${ }^{[25]}$ The Pt utilization for this membrane was $8,231 \mathrm{~mW}$ $\mathrm{mg}_{\mathrm{Pt}}{ }^{-1}$, compared to a standard E-TEK (Pt/XC-72) electrocatalyst $\left(4,702 \mathrm{~mW} \mathrm{mg}_{\mathrm{Pt}^{-}}{ }^{-1}\right) \cdot{ }^{[25]}$ Our approach involves using layer-by-layer (LBL) assembly to successfully integrate disparate materials. ${ }^{[26-31]}$ This method, which was developed by Decher et al., allows the deposition of polyelectrolyte multilayered films on almost any kind of surface regardless of its shape, and with a wide choice of possible polyelectrolytes. ${ }^{[32,33]}$ Later Kotov et al., extended it to nanoparticles, ${ }^{[30]}$ graphite oxide sheets ${ }^{[34]}$ and single walled ${ }^{[35]}$ and multiwalled carbon nanotubes. ${ }^{[36]}$ Previously, Farhat and Hammond demonstrated a fuel cell with a LBL poly(ethylene oxide)/poly(acrylic acid) composite membrane that yielded a peak power density of $16.5 \mathrm{~mW}$ $\mathrm{cm}^{-2} \cdot{ }^{[37]}$ We recently demonstrated fuel cells with LBL catalyst layers comprised of SWCNTs and CFs that exhibited peak power densities of $195 \mathrm{~mW} \mathrm{~cm}^{-2}$ and $227 \mathrm{~mW} \mathrm{~cm}^{-2}$ and Pt utilizations of $408 \mathrm{~mW} \mathrm{mg}{ }^{-1} \mathrm{Pt}$ and $580 \mathrm{~mW} \mathrm{mg}{ }^{-1} \mathrm{Pt}$ respectively. ${ }^{[38]}$ To achieve these results, we used selective heterogeneous nucleation $^{[39]}$ to deposit Pt on the surface of the SWCNTs and CFs with Nafion and polyethyleneimine (PEI) as the polyelectrolytes. In this paper we will report fuel cell results for LBL SWCNTs functionalized with Pt using a supercritical fluid method with Nafion and polyaniline as the polyelectrolytes. These layers were evaluated for the first time as catalyzed gas diffusion layers (CGDLs). We will also report improved fuel cell results using thinner (reduction from 200 to 100 bilayers) LBL carbon fiber catalyst layers functionalized with Pt using selective heterogeneous nucleation. Although layered deposition is more time consuming than standard manufacturing techniques, the ability of LBL assembly to control the nanoscale (and to some degree the microscale) morphology provides an important tool for the systematic empirical study of optimal structure of CGDLs.

\section{Results and Discussion}

\subsection{Pt/SWCNT Electrocatalyst}

The Pt/SWCNT electrocatalysts consisted of SWCNTs functionalized with $\mathrm{Pt}$ via processing with supercritical (SC) methanol. This method avoids harsh oxidative pretreatments (i.e., refluxing in oxidizing acid or UV radiation) typically used to functionalize 1D carbon materials with carboxyl groups prior to metal functionalization. ${ }^{[40-43]}$ Compared to electrodeposition, ambiguity associated with the concurrent reduction of $\mathrm{H}^{+}$is avoided due to the non-ideal current efficiency for $\mathrm{Pt}$ deposition which makes it difficult to accurately determine the metal loading. ${ }^{[7,44]}$ In our previous work, we varied the supercritical fluid synthesis conditions to determine how this influenced the Pt particle size and fuel cell catalyst performance. ${ }^{[45]}$ By comparing various carbon supports (i.e., SWCNTs, CFs, and carbon black [XC-72] under the exact same loading conditions it was found that $\mathrm{Pt} / \mathrm{SWCNTs}$ gave the best performance (Pt utilizaition) followed by $\mathrm{Pt} / \mathrm{CFs}^{[45]} \mathrm{Pt}$ utilizations are typically higher using SWCNT and CF supports because some Pt particles are isolated (not active) inside the inner pores of carbon black materials.

Transmission electron microscopy (TEM) was used to determine Pt nanoparticle sizes. Micrographs for SWCNTs functionalized with $\mathrm{Pt}$ using the SC method are illustrated in Figure $1 \mathrm{~A}$ and $\mathrm{B}$. The Pt loading of this material was $47.3 \mathrm{wt} \%$. Figure 2 illustrates the particle size distribution determined by measuring the sizes of more than $300 \mathrm{Pt}$ particles. The average particle size was $(4.3 \pm 3.0) \mathrm{nm}$. Approximately $90 \%$ of the particles are smaller than $7.5 \mathrm{~nm}$. Note that the Pt particle size of the standard catalyst was measured to be $(3.0 \pm 2.1) \mathrm{nm} .{ }^{[45]}$ The BET surface areas of the SWCNTs before and after Pt loading were $610 \mathrm{~m}^{2} \mathrm{~g}^{-1}$ and $400 \mathrm{~m}^{2} \mathrm{~g}^{-1}$, respectively. Membrane electrode assemblies were produced using a catalyst ink formulation described in the experimental section and a hand painting technique described previously. ${ }^{[16]}$
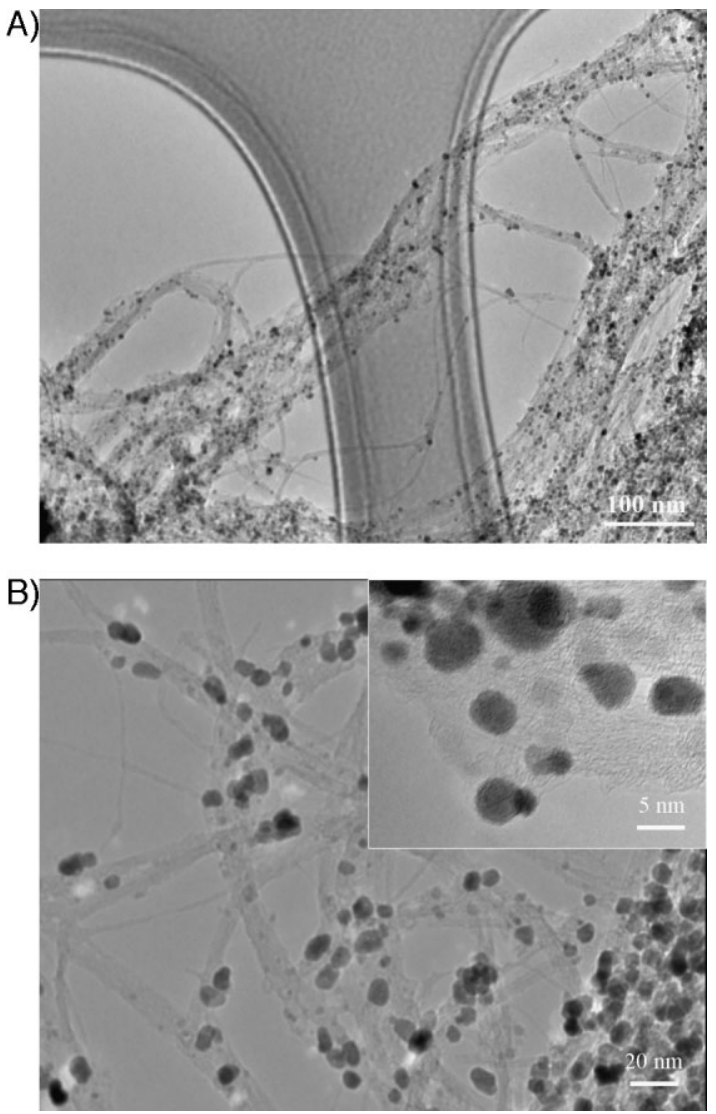

Figure 1. A,B) Transmission electron microscopy images of Pt nanoparticles on SWCNTs (protected using the SC method). 


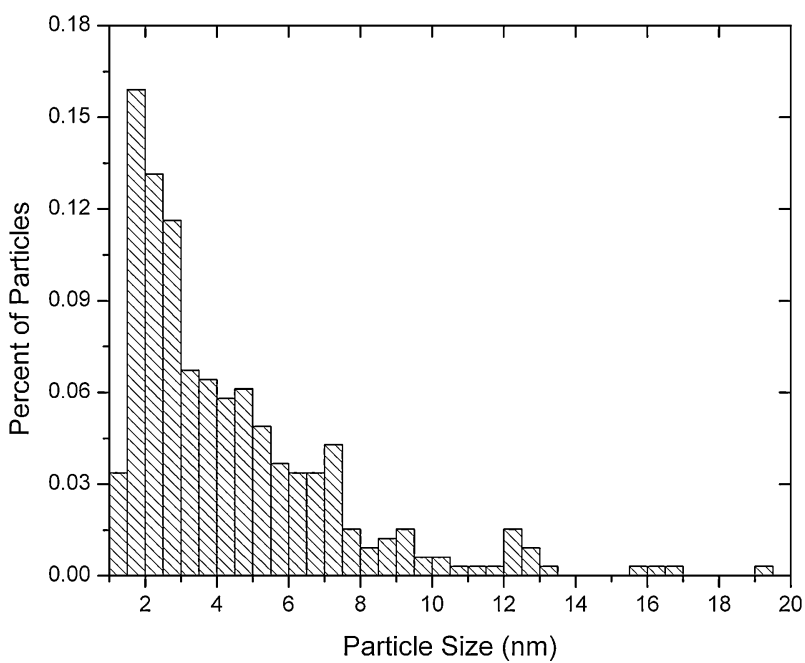

Figure 2. Pt particle size distribution on SWCNTs using the SC method, with a Pt loading of $47.3 \%$

Figure 3 illustrates the performance of the Pt/SWCNT catalyst material.

The Pt/SWCNT MEA had an anode and cathode loading of $0.56 \mathrm{mg}_{\mathrm{Pt}} \mathrm{cm}^{-2}$ and $0.49 \mathrm{mg}_{\mathrm{Pt}} \mathrm{cm}^{-2}$, respectively, with a peak power density of $230 \mathrm{~mW} \mathrm{~cm}^{-2}$. For comparison, an MEA using standard catalysts and Pt loading $\left(0.5 \mathrm{mg}_{\mathrm{Pt}} \mathrm{cm}^{-2}\right)$ under the similar conditions was reported to yield a peak power density of $400 \mathrm{~mW} \mathrm{~cm}{ }^{-2}$.10] Note that the ink preparation method for the Pt/SWCNT MEAs was not optimized for the hydrophobic SWCNTs. This could limit the intimate contact necessary to create triple phase boundary regions. The previous work from Tang et al. demonstrated an improvement using Pt/SWCNTs over conventional catalysts on the cathode side. Unfortunately, these Pt/SWCNT mats were not evaluated on the anode side. ${ }^{[25]}$ Nevertheless, the results were encoura-

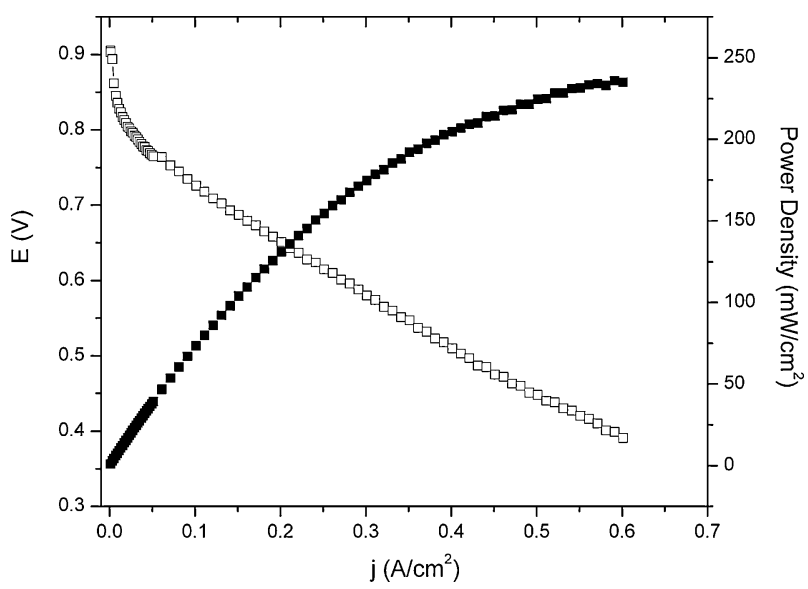

Figure 3. Pt/SWCNTs fuel cell polarization and peak power density. Fue cell temperature of $80^{\circ} \mathrm{C}$ with saturators at $90^{\circ} \mathrm{C}$. The $\mathrm{H}_{2}$ and $\mathrm{O}_{2}$ flow rates were $100 \mathrm{sccm}$ at $100 \%$ relative humidity. Open symbols - polarization; closed symbols - power density. ging as a means to investigate whether the Pt/SWCNT catalyst is a viable fuel cell electrocatalyst for anodes and cathodes produced using LBL techniques.

\subsection{Layer-by-Layer Fabrication of Catalyzed Gas Diffusion Layer}

The catalyzed gas diffusion layers (CGDL) were constructed using the Pt functionalized SWCNTs, Nafion ${ }^{\circledR}$ $\left(2 \mathrm{mg} \mathrm{mL}{ }^{-1}\right)$ and a polycation [polyaniline (PANI)]. The Nafion ${ }^{\mathbb{B}}$ solution served as a solubilizing agent for the $\mathrm{Pt} /$ SWCNTs due to the hydrophobicity of the PTFE backbone structure. The hydrophilic branched chain with the sulfate group allows this polymer to dissolve in lower aliphatic alcohols and water mixtures. ${ }^{[46]}$ Successful dispersions were achieved in equal amounts of ethanol and water. We observed that the Pt/SWCNTs functionalized using the SHN method, described by Wang et al. ${ }^{[39]}$ were easier to disperse than the $\mathrm{Pt} /$ SWCNTs created using the SC method. While the functional groups created by nitric acid exposure during the SHN method facilitate the dispersion, these same functional groups could have a deleterious effect on the durability of the SWCNTs. ${ }^{[47]}$ PANI was selected as the polycation due to its high electrical conductivity and established compatibility with LBL processing. ${ }^{[48]}$ The films were constructed due to the electrostatic interactions of the negatively charged Pt/SWCNT and the PANI. We note that Farhat used two (polyanionic and polycationic) dispersions of carbon black to insure acceptable electrical conductivity and good catalyst loading in their LBL films. ${ }^{[4]}$ Although the PANI polycation solution was electrically conductive, it was not necessary to create two dispersions of the Pt/SWCNTs. The long length scales of the SWCNTs ensured good catalyst loading and conductivity throughout the film. We also did not observe any evidence of phase separation from the constructed films. All of the constructed films were made up of 400 bilayers that will be described as [PANI-(Pt/SWCNTs+Nafion $)]_{400}$.

The LBL-CGDLs (free standing films) were constructed into membrane electrode assemblies and tested in a fuel cell test station. Figure 4 illustrates a series of polarization (hollow points) and power density curves (solid points) for several $\left[\text { PANI- }\left(\mathrm{Pt} / \mathrm{SWCNTs}+\mathrm{Nafion}{ }^{\mathrm{R}}\right)\right]_{400}$ MEAs. The variations represent the evaluation of these LBL films as catalyst layers and catalyzed gas diffusion layers.

Typically MEAs are hot pressed $\left(135^{\circ} \mathrm{C}\right.$ for $5 \mathrm{~min}$ at $10 \mathrm{MPa}$ ) to improve intimate contact between the electrodes, catalyst, and Nafion membrane. In the first example (Fig. 4, square points), the thin film was treated as a catalyst layer and was placed between a GDL and a Nafion 117 membrane on the anode side followed by a standard catalyst $\left(0.5 \mathrm{mg} \mathrm{Pt} \mathrm{cm}{ }^{-2}\right)$ with GDL on the cathode. The peak power density for

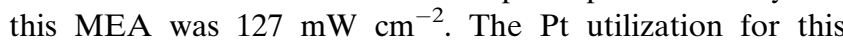

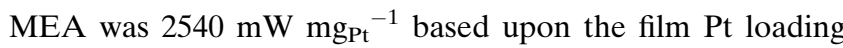
$\left(0.05 \mathrm{mg} \mathrm{Pt} \mathrm{cm}^{-2}\right)$ determined by thermogravimetric analysis (TGA) methods described previously. ${ }^{[16]}$ The Pt utilization for 


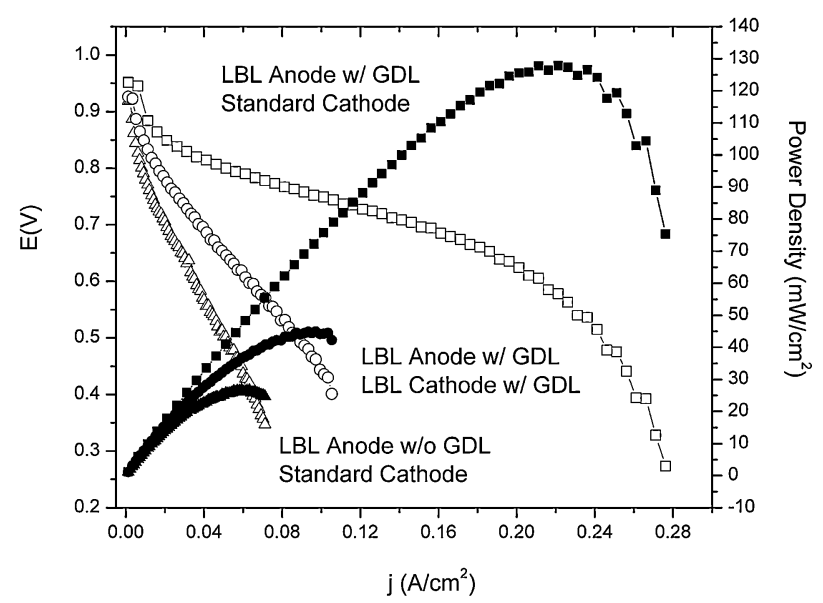

Figure 4. Fuel Cell MEA Polarization curves illustrating [PANI-(Pt/ SWCNTs+Nafion $\left.\left.{ }^{\mathbb{R}}\right)\right]_{400}$ (SC Method). Fuel cell temperature: $80^{\circ} \mathrm{C}$ and saturators: $90^{\circ} \mathrm{C} . \mathrm{H}_{2}$ and $\mathrm{O}_{2}$ flow rates: $100 \mathrm{sccm}$, at $100 \%$ relative humidity. Standard cathode refers to $\mathrm{Pt} / \mathrm{CB}$ using a GDL (see experimental section). Open symbols - polarization; closed symbols - power density.

this film was substantially higher than our standard catalyst $\left(\sim 800 \mathrm{~mW} \mathrm{mg}_{\mathrm{Pt}}{ }^{-1}\right)$.

The second example (circle points) was the same as the first except the standard cathode catalyst were replaced with an LBL thin film. Here LBL thin films were evaluated as catalyst layers for both the anode and cathode. The peak power density for this film dropped to $45 \mathrm{~mW} \mathrm{~cm}^{-2}$. Although the peak power density significantly decreased, we observed that the total Pt utilizations between the LBL MEA and the hand painted MEAs were similar. The total amount of Pt (summing the anode and cathode loadings) for the LBL MEA was $0.1 \mathrm{mg}_{\mathrm{Pt}}$ $\mathrm{cm}^{-2}$ giving a Pt utilization of $450 \mathrm{~mW} \mathrm{mg}_{\mathrm{Pt}}{ }^{-1}$ compared to the hand painted MEA that had $1.05 \mathrm{mg}_{\mathrm{Pt}} \mathrm{cm}^{-2}$ and gave a $\mathrm{Pt}$ utilization of $219 \mathrm{~mW} \mathrm{mg}_{\mathrm{Pt}^{-1}}{ }^{-1}$. This would suggest that the performance of the LBL film could be further improved by loading more catalyst sites into the thin films. We note that $\mathrm{Pt}$ loaded PANI has been successfully demonstrated as a fuel cell catalyst which could be a pathway to achieve higher $\mathrm{Pt}$ utilization and performance. ${ }^{[35]}$

The third example (triangle points) treats the thin film as a catalyzed gas diffusion layer for the anode with a standard cathode catalyst and GDL. The peak power density for this MEA was $27 \mathrm{~mW} \mathrm{~cm}^{-2}$. Although using the layer-by-layer nanocomposite catalyst layers (LNCLs) as a catalyzed GDL lowered the performance of the system, the results are encouraging for further investigation. Typical GDLs are made from woven carbon fibers saturated with carbon and proprietary dewetting agents (E-Tek). The main function of the GDL is to distribute the fuel and oxidant through an electrically conductive medium that prevents water from forming a diffusion barrier to the catalyst layer. From this perspective it is conceivable that the layer can be improved using LBL with the proper materials and polyelectrolytes. To our knowledge this is first time an LBL catalyst layer has been evaluated in a fuel cell in this way. An ideal catalyst would completely eliminate the use of precious metals such as $\mathrm{Pt}$, and there have been some interesting results presented by Bashyam and Zelenay using cobalt-polypyrrole composites. ${ }^{[50]}$ Another example presented by Nakamura et al. demonstrated the possibility of using $\mathrm{Mo}_{2} \mathrm{C} / \mathrm{CNT}$ s for use in a fuel cell. ${ }^{[21]} \mathrm{As}$ these materials are further developed to achieve performance results similar to $\mathrm{Pt}$ based catalysts, LBL assembly techniques such as those demonstrated in this work could prove useful as a means to integrate these materials.

\subsection{Modified Construction of Layer-by-Layer Nanocomposite Catalyst Layers}

From the shape of the polarization curve for the MEA illustrated in Figure 4 (LBL Anode with GDL and standard cathode) it appears to be mass transport limited. This is evident from the slope of the curve from 0.20 to $0.27 \mathrm{~A} \mathrm{~cm}^{-2}$. To address these limitations, LBL systems using carbon fibers (CFs) were developed. The fibers have a larger diameter ranging from $\quad 30-45 \mathrm{~nm}$ compared to the SWCNTs $(5-8 \mathrm{~nm})$. The polycation in this case was polyethyleneimine (PEI) because PANI did not work very well with the CFs. This could be due to the fact that the molecular structure of the PANI was not large enough to accommodate for the larger CFs to form sufficient TPB regions. The CFs were functionalized with $\mathrm{Pt}$ using selective heterogeneous nucleation methods described previously. ${ }^{[38,39]}$ The $\mathrm{Pt}$ particle sizes ranged from 1.5 to $2.6 \mathrm{~nm}$ as described previously. ${ }^{[38]}$ A departure from our previous work with the $[\mathrm{PEI}-(\mathrm{Pt} / \mathrm{CFs}+\mathrm{Nafion})]_{400}$ system is that we did not use a rinsing step for these films. The rinsing step typically removes excess materials during LBL film growth, however the elimination of this step did not produce any noticeable degradation in the quality of our films.

From the SEM image shown in Figure 5 it was observed that the CFs were loosely tangled as they were incorporated into the film. Figure 6 illustrates the performance of two LBL (Pt/ CFs thin films) catalyst layers. The LNCLs were composed of [PEI-(Pt/CFs+Nafion) $]_{\mathrm{n}}$ where $N=100\left(0.12 \mathrm{mg} \mathrm{Pt} \mathrm{cm}^{-2}\right)$ and 200 ( $\left.0.21 \mathrm{mg} \mathrm{Pt} \mathrm{cm}^{-2}\right)$ bilayers, respectively. We note that we were not able to produce freestanding films for 100 and 200 bilayers with the rinsing steps. The films were evaluated on the anode with a GDL and standard cathode catalyst $(0.5 \mathrm{mg}$

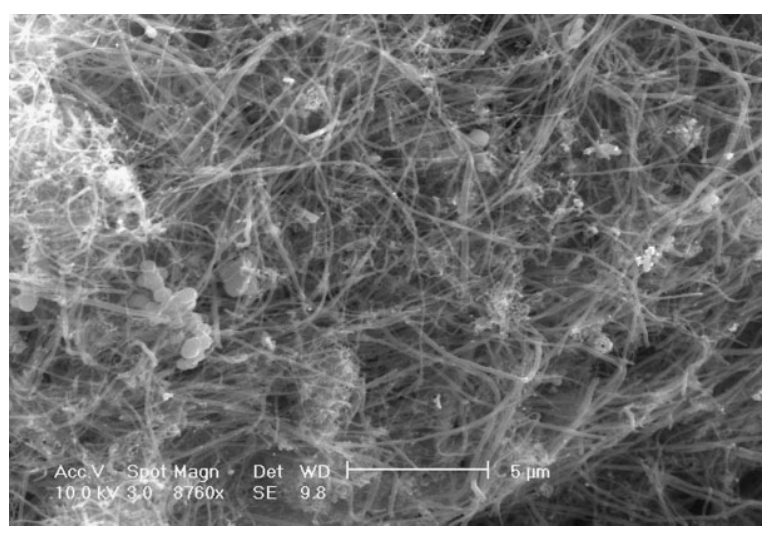

Figure 5. SEM image of $\left[\mathrm{PEI}-\left(\mathrm{Pt} / \mathrm{CF}+\mathrm{Nafion}{ }^{\circledR}\right)\right]_{200}$ catalyst membrane. 


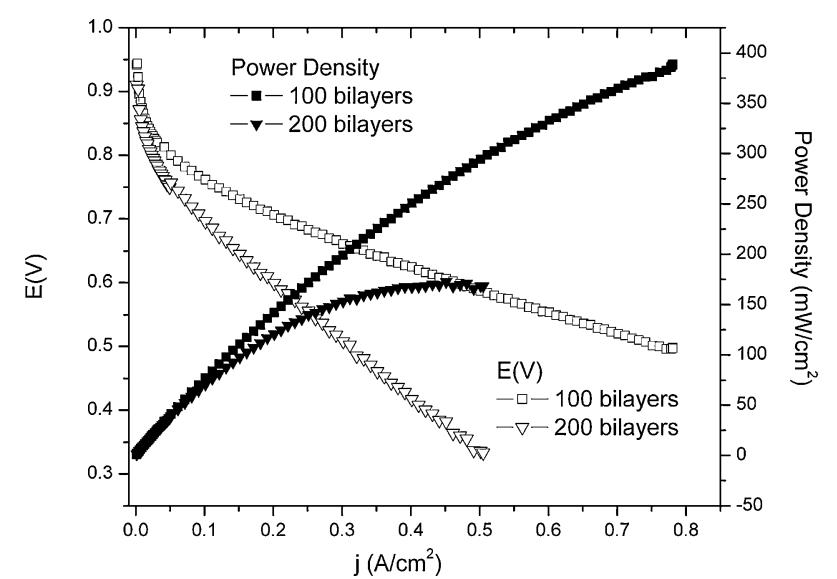

Figure 6. Fuel Cell MEA Polarization curves illustrating [PEI-(Pt/ $\mathrm{CNFs}+$ Nafion) $]_{\mathrm{N}=(100,200)}$ (SHN Method). Fuel cell temperature: $80^{\circ} \mathrm{C}$ and saturators: $90^{\circ} \mathrm{C} . \mathrm{H}_{2}$ and $\mathrm{O}_{2}$ flow rates: $100 \mathrm{sccm}$, at $100 \%$ relative humidity. Open symbols - polarization; closed symbols - power density.

$\mathrm{Pt} \mathrm{cm}^{-2}$ ). From the results, the thick film catalyst layer had a peak power density of $172 \mathrm{~mW} \mathrm{~cm}{ }^{-2}$ compared to the thinner film of $387 \mathrm{~mW} \mathrm{~cm}^{-2}$. This suggests that a thinner film could improve performance, which is greatly aided by the excellent mechanical properties of LBL films from SWCNTs unlike the mats made from the same material. ${ }^{[51,52]}$ However, even for LBL composites, the robustness of the films was compromised (after substrate detachment) at thicknesses below 200 bilayers which indicates that electrical, catalytic properties and mechanical strength need to be further integrated. To the best of our knowledge these are among the highest power densities for films of this type. The Pt utilization for this film was determined to be $3198 \mathrm{~mW} \mathrm{mg}_{\mathrm{Pt}}{ }^{-1}$ and is almost an order of magnitude higher than our standard MEAs. Two possible reasons for the higher power density achieved by eliminating the rinsing step is that the material is not as tightly bonded between each layer of the film and the reduced thickness of the films. The exceptionally high homogeneity of LBL films compared to other methods of preparation of SWCNT composites provides efficient distribution and accessability of $\mathrm{Pt}$ nanoparticles and prevents their spontaneous aggregation. Additionally, by allowing the film to build up in this way, more of the $-\mathrm{SO}_{3} \mathrm{H}^{+}$groups of the Nafion wrapped $\mathrm{Pt} / \mathrm{CFs}$ are exposed and able to participate in the water facilitated Grotthuss-hopping mechanism. At very low water content, Nafion behaves like a semiconductor where the hopping of the proton through a chain of hydrogen bonded water molecules takes place ${ }^{[53,54]}$ The use of polyethyleneimine (PEI) adds to the overall strength of the LNCL thin films. PEI has previously been blended with brittle sulfonated polysulfone and sulfonated poly(etheretherketone) to create acid-base blends for the replacement of Nafion proton exchange membranes. ${ }^{[55]}$ From the results presented, the membranes showed good proton conductivities at ion-exchange capacities IEC of 1 (IEC $=$ meg $\mathrm{SO}_{3} \mathrm{H} \mathrm{g}^{-1}$ dry membrane), and showed excellent thermal stabilities (decomposition temperatures $>270{ }^{\circ} \mathrm{C}$ ), which is desirable for high temperature fuel cells. ${ }^{[5]}$

\section{Conclusions}

In this work, we describe two methods of functionalizing SWCNTs and CFs as well as the use of LBL methods to construct films and MEAs. The SWCNTs were functionalized with Pt using supercritical methanol. Using PANI as the polycation and Nafion solubilized Pt/SWCNTs as the polyanion freestanding LBL films were fabricated. These films were evaluated as both a catalyst layer and a catalyzed gas diffusion layer. $[\mathrm{PANI}(\mathrm{Pt} / \mathrm{SWCNTs}+\mathrm{Nafion})]_{400}$ system demonstrated a peak power density of $127 \mathrm{~mW} \mathrm{~cm}^{-2}$ and a $\mathrm{Pt}$ utilization of $2540 \mathrm{~mW} \mathrm{mg} \mathrm{Pt}^{-1}$. PANI with solubilized $\mathrm{Pt} /$ CFs films did not yield useful fuel cell results. By selecting the right polyelectrolytes and modifying our synthesis method, we have further demonstrated that improvements can be realized. Here $\mathrm{CFs}$ were functionalized with $\mathrm{Pt}$ using selective heterogeneous nucleation. A departure from our previous work involved omitting the rinsing steps typically used to build our films. It was found that the thinner film [PEI-(Pt/ CNFs+Nafion) $]_{100}$ of 100 bilayers gave the best performance with a peak power density of $387 \mathrm{~mW} \mathrm{~cm}^{-2}$ and a Pt utilization of $3198 \mathrm{~mW} \mathrm{mg}_{\mathrm{Pt}}{ }^{-1}$. These utilizations were substantially higher than that for our standard catalyst, which was $800 \mathrm{~mW}$ $\mathrm{mg}_{\mathrm{Pt}^{-1}}{ }^{-1}$. To the best of our knowledge, these values demonstrate the highest performance in the literature for films of this type.

Finally, a few words need to be said about the practicality of the presented research. Despite very competitive performance we treat the LBL assembly method of fuel cell components as a research tool undergoing transition to industrial practice. It helps one to identify the best configuration and morphology of the gas diffusion layer and catalytic layer because it offers a high degree of control over the film structure compared to all the other methods. The trade-off for high degree of structural control is the time spent on manufacturing of the films. Recent advances in LBL allows one to drastically shorten the time necessary for layered assembly using dewetting $\mathrm{LBL}^{[56]}$ and potentially exponential LBL. ${ }^{[57,58]}$

\section{Experimental}

Chemicals and Materials: Deionized water (18MOhm) from a Barnstead E-pure system was used to create all of the polyeletrolyte and rinse solutions. The following chemicals were obtained from Sigma-Aldrich: polyethyleneimine [PEI; $\left.\left(M_{\mathrm{W}}\right)=25,000\right]$; dihydrogen hexachloroplatinate $\left(\mathrm{H}_{2} \mathrm{PtCl}_{6}\right)$, sodium dodecyl sulfate (SDS), and Nafion perfluorinated ion-exchange resin $[5 \mathrm{wt} \%$ sol in lower aliphatic alcohols/H2O mix (used for the standard fuel cell catalyst blend]). Platinum acetylacetonate $\left[\mathrm{Pt}(\mathrm{Acac})_{2}\right]$ was purchased from Fisher Scientific. HiSPECTM 3000 (platinum, nominally $20 \%$ on carbon black) was obtained from Alfa Aesar (Johnson Matthey Company). The Nafion 117 membranes [(DuPont) Ion Power, New Castle, DE] 
were cleaned using procedures published in the literature. Briefly, the membranes were pretreated by boiling in $50 \mathrm{vol} \% \mathrm{HNO}_{3}$ (to remove orgainics) and deionized water for 1 hour, rinsing in boiling deionized (DI) water for 30 minutes, boiling in $0.5 \mathrm{M} \mathrm{H}_{2} \mathrm{SO}_{4}$ solution for $30 \mathrm{~min}$, and boiling twice in DI water for 30 minutes. The membranes were subsequently stored in deionized water until ready for use. The singlewalled carbon nanotubes created using the HiPco process (impurities: 6-14\%) were obtained from Carbon Nanotechnologies Incorporated (CNI), Houston, Texas. The Pyrograf III ${ }^{\circledR}$ carbon nanofibers were catalytically grown and obtained from Pyrograf Products Inc., (Applied Sciences Inc. subsidiary, Cedarville, $\mathrm{OH}$ ). To create the carbon dispersions, Nafion 117 (5\% resin solution) was obtained from Fluka. Teflon emulsion, PTFE 30, was purchased from Fuel Cell Scientific, Stoneham, MA. ELAT V3.1 double side automated gas diffusion layers (GDLs) were purchased from E-TEK, the fuel cell division of PEMEAS, Somerset, NJ.

Instrumentation: A Model ASAP 2010 (Micromeritics Instrument Corporation) was used to obtain the Brunauer, Emmett, and Teller (BET) surface areas of the carbon-supported nanocomposites. A VWR Model 150HT ultrasonic cleaner was used to sonicate the polyelectrolyte solutions. To determine the actual loadings of the prepared catalyst materials, a thermal gravimetric analysis (Model SDT Q600 Instrument, TA Instruments, Inc.) was used. For this anlysis, experiments were conducted by increasing the sample temperature to $1000^{\circ} \mathrm{C}$. Steep reductions in mass were observed at approximately $420^{\circ} \mathrm{C}$ where the carbon supports were starting to be consumed, leaving the Pt particles behind. At $1000^{\circ} \mathrm{C}$ it was assumed that all the carbon support had been removed from the sample and only oxidized $\mathrm{Pt}$ particles remained as $\mathrm{PtO}$. Catalyst loadings were then calculated based on the beginning mass of the $\mathrm{Pt} / \mathrm{C}$ nanocomposite and ending mass of the remaining PtO particles. The amount of Pt in the LBL films was measured the same way assuming that all the polyelectrolytes (Nafion, PEI) were completely burned off at $1000^{\circ} \mathrm{C}$. A Philips XL30 field emission gun scanning electron microscope (SEM) was used to capture the SEM images. A JEOL 3011 high-resolution electron microscope was used for the transmission electron microscopy (TEM) images.

Preparation of Pt-Loaded SWCNTs and CFs: Supercritical Fluid Method (SC): Using a $4.1 \mathrm{~mL}$ stainless steel reactor, SWCNTs $(35.0 \mathrm{mg})$, platinum (II) acetylacetonate $(87.5 \mathrm{mg})$, and methanol $(3.28 \mathrm{ml})$ were combined. The contents were sealed and placed into a sand bath at $300^{\circ} \mathrm{C}$ for 30 minutes. Under these conditions the $\mathrm{MeOH}$ becomes a supercritical fluid capable of reducing the platinum (II) acetylacetonate. This formulation results in a Pt/SWCNT catalyst that has a nominal loading of $55 \mathrm{wt} \% \mathrm{Pt}$. The Pt/SWCNT was then filtered and rinsed several times in ethanol and dried at $60-80^{\circ} \mathrm{C}$ under vacuum for $24 \mathrm{~h}$. The functionalized SWCNTs will be referred to as Pt/SWCNT.

Selective Heterogeneous Nucleation ( $S H N$ ): Prior to functionalization, the $\mathrm{CF}$ supports were oxidized in a sonicated solution of $\mathrm{HNO}_{3}$ for $1 \mathrm{~h}$ (VWR Model 150HT ultrasonic cleaner) at ambient conditions. The resulting materials were filtrated, rinsed several times with ethanol and dried at $60^{\circ} \mathrm{C}$ under vacuum for $24 \mathrm{~h}$. Chloroplatinic acid $\left(\mathrm{H}_{2} \mathrm{PtCl}_{6}\right)$ was used as the platinum precursor, and ethylene glycol (EG) as the solvent and reducing agent. Sodium dodecyl sulfate (SDS) was added to the reaction system and dissolved by mixing. The oxidized SWCNT or CF $(100 \mathrm{mg})$ were mixed with a solution of SDS $(2 \%)$ in EG $(200 \mathrm{~mL})$. After ultrasonication of the mixture for $1 \mathrm{~h}$, a solution of $\mathrm{H}_{2} \mathrm{PtCl}_{6}(0.5 \mathrm{~g}$ $\left.\mathrm{mL}^{-1}\right)$ in EG $(20 \mathrm{~mL})$ was added with constant agitation. The mixture was then heated at $150^{\circ} \mathrm{C}$, and aged for $30 \mathrm{~min}$ with vigorous agitation to ensure completion of the reaction. The products were filtrated, rinsed several times with ethanol and dried at $60^{\circ} \mathrm{C}$ under vacuum for $24 \mathrm{~h}$. The functionalized $\mathrm{CF}$ will be referred to as $\mathrm{Pt} / \mathrm{CF}$.

Preparation of Carbon-Polyelectrolyte Nanocolloids and $L B L$ Deposition: Functionalized Pt/SWCNT and Pt/CF were dispersed in a solution of Nafion $\left(2 \mathrm{mg} \mathrm{mL}^{-1}\right)$ in ethanol/water $(70: 30)$ with $30 \mathrm{~min}$ of ultrasonication. These dispersions were used for one LBL component. The PANI solutions and water rinsing steps resembled the steps described in previous literature. [48] Briefly, PANI solution $\left(1 \mathrm{mg} \mathrm{mL}^{-1}\right)$ was prepared as a polycation solution at a $\mathrm{pH}$ of 2.5 . PEI solution $\left(1 \mathrm{mg} \mathrm{mL}^{-1}\right)$ was prepared as another LBL partner at a $\mathrm{pH}$ of 8.5. The procedures of LBL assemblies of SWCNT and CF resembled those that were described in previous publications [51,59]. Briefly, the $(\mathrm{Pt} / \mathrm{SWCNT}$ or $\mathrm{Pt} / \mathrm{CF})+$ Nafion nanocomposites were assembled on to solid supports by alternate dipping of a solid substrate (glass slides or silicon wafers) into dispersions of carbon nanocolloids and polyelectrolyte solutions. The wafers/slides were cleaned in piranha solution (a 1:3 mixture of $30 \% \mathrm{H}_{2} \mathrm{O}_{2}$ and concentrated $\mathrm{H}_{2} \mathrm{SO}_{4}$; Note- dangerous mixture that violently reacts with organics); rinsed in deionized water, sonicated for $15 \mathrm{~min}$ and again thoroughly rinsed with deionized water. They were then coated with a PEI precursor layer.

The layer sequence for the (PANI) $[\mathrm{Nafion} /(\mathrm{Pt} / \mathrm{SWCNT})]$ was repeated using rinse solutions ( $\mathrm{pH}$ 2.5) until the desired thickness was achieved. The layer sequence of (PEI) [Nafion/(Pt/CFs)] was repeated until the desirable thickness was obtained. Exposure times of $10 \mathrm{~min}$ were used for polyelectrolytes and (SWCNT or CF) baths. Through charge transfer interaction between the Nafion wrapped around the SWCNT or CF and polycation (PANI or PEI), an LBL assembly on a charged substrate (glass or $\mathrm{Si}$ ) is formed. The PANI LBL layering cycle consists of the following steps: $10 \mathrm{~min}$ dip in PANI $\left(1 \mathrm{mg} \mathrm{mL}^{-1}\right), 3 \mathrm{~min}$ rinse in deionized water $\left(\mathrm{H}_{2} \mathrm{O}\right), 10$ minutes drying under $\mathrm{N}_{2}, 10$ min dip in $\mathrm{Pt} / \mathrm{SWCNT}$ or $\mathrm{Pt} / \mathrm{CFs}$ dispersed in Nafion, a 3 min rinse in deionized water $\left(\mathrm{H}_{2} \mathrm{O}\right)$, and a 10 min drying under $\mathrm{N}_{2}$. The PEI LBL layering cycle is the same as the PANI without the deionized water rinsing steps.

The assembly conditions of the entire procedure (such as $\mathrm{pH}$, ionic strengths, and concentrations) were optimized so that the dipping cycles could be repeated as many times as needed with linear growth of the multilayers. An example notation of the LBL assembly listed as $[\text { polycation/(catalyst+polyanion) }]_{n}$ where $\mathrm{n}$ represents the number of repeated dipping processes (bilayer) in the different solutions. Hence a representative $\mathrm{LBL}$ film listed as $[\mathrm{PANI} /(\mathrm{Pt} / \mathrm{SWCNT}+\mathrm{Nafion})]_{400}$ represents a 400 bilayers nanocomposite film consisting of PANI, Pt functionalized single-walled carbon nanotubes, and Nafion.

MEA Construction and Fuel Cell Testing: Freestanding LBL films were evaluated as anodes and cathodes and were placed between the GDL and the Nafion 117 membrane. For evaluation as a catalyzed gas diffusion layer, the LBL film was attached only to the Nafion 117 (without using a GDL). Hispec $3000^{\mathrm{TM}} \mathrm{Pt} / \mathrm{C}(20 \% \mathrm{Pt}$ loading) was used to create the standard catalyst ink solutions. The cathode catalyst layers were made from an ink solution made of Pt/C (68\%), Nafion $(20 \%)$, and PTFE $(12 \%)$. The ink solutions were painted onto the GDLs for a desired Pt loading using a hand painting (screen printing) technique described previously. [16] The Pt loading of the cathode layers was $\sim 0.5 \mathrm{mg} \mathrm{cm}^{-2}$. They were placed between the GDL and the Nafion 117 membrane. The Pt loading of the LBL layers was determined by TGA analysis. The MEAs were made by hot pressing the LBL membrane in between two GDLs at $135^{\circ} \mathrm{C}$ for $5 \mathrm{~min}$ at a pressure of $10 \mathrm{MPa}$. The MEAs were tested in single fuel cell housing and were conditioned over night until a steady state current was achieved at a potential of $0.6 \mathrm{~V}$. The temperature of the fuel cell was $80^{\circ} \mathrm{C}$ and the anode and cathode saturators were set at $90^{\circ} \mathrm{C}$. The flow rates of the humidified hydrogen and oxygen were set at $100 \mathrm{sccm}$. An Agilent electronic load controlled the cell potential and a National Instruments data acquisition system controlled the inputs. The operation of fuel cell test station was controlled and monitored by LabView ${ }^{\mathbb{R}}$ programs written by the first author. The data presented in this work are not corrected for internal resistance.

Received: December 24, 2007 Revised: May 16, 2008 Published online: September 24, 2008

[1] J. Larminie, A. Dicks, Fuel Cell Systems Eexplained, Wiley, Chichester, UK 2003

[2] J. D. Morse, R. S. Upadhye, R. T. Graff, C. Spadaccini, H. G. Park, E. K. Hart, J. Micromech. Microeng. 2007, 17, S237. 
[3] A. D. Taylor, L. T. Thompson, in IEEE Solid State Sensors and Actuators Workshop, Transducers Research Foundation, Hilton Head, SC 2004, 24.

[4] M. S. Wilson, S. Gottesfeld, J. Electrochem. Soc. 1992, 139, L28.

[5] E. J. Carlson, P. Kopf, J. Sinha, S. Sriramulu, Y. Yang, TIAX LLC NREL Report-NREL/SR-560-39104, U.S. Department of Energy, Washington, DC 2005.

[6] S. Srinivasan, O. A. Velev, A. Parthasarathy, D. J. Manko, A. J. Appleby, J. Power Sources 1991, 36, 299.

[7] J. H. Wee, K. Y. Lee, S. H. Kim, J. Power Sources 2007, 165, 667.

[8] S. Hirano, J. Kim, S. Srinivasan, Electrochim. Acta 1997, 42, 1587.

[9] R. O'Hayre, S. J. Lee, S. W. Cha, F. B. Prinz, J. Power Sources 2002, $109,483$.

[10] A. D. Taylor, B. D. Lucas, L. J. Guo, L. T. Thompson, J. Power Sources 2007, 171, 218.

[11] T. R. Ralph, G. A. Hards, J. E. Keating, S. A. Campbell, D. P Wilkinson, M. Davis, J. StPierre, M. C. Johnson, J. Electrochem. Soc. 1997, 144, 3845.

[12] X. W. Yu, S. Y. Ye, J. Power Sources 2007, 172, 133.

[13] J. Lobato, M. A. Rodrigo, J. J. Linares, K. Scott, J. Power Sources 2006, 157, 284.

[14] S. J. Shin, J. K. Lee, H. Y. Ha, S. A. Hong, H. S. Chun, I. H. Oh, J. Power Sources 2002, 106, 146.

[15] L. Xiong, A. Manthiram, Electrochim. Acta 2005, 50, 3200.

[16] A. D. Taylor, E. Y. Kim, V. P. Humes, J. Kizuka, L. T. Thompson, J. Power Sources 2007, 171, 101.

[17] S. D. Thompson, L. R. Jordan, M. Forsyth, Electrochim. Acta 2001, 46, 1657.

[18] M. Uchida, Y. Fukuoka, Y. Sugawara, H. Ohara, A. Ohta, J. Electrochem. Soc. 1998, 145, 3708 .

[19] K. Lee, J. J. Zhang, H. J. Wang, D. P. Wilkinson, J. Appl. Electrochem 2006, 36, 507 .

[20] G. G. Wildgoose, C. E. Banks, R. G. Compton, Small 2006, 2, 182.

[21] T. Matsumoto, Y. Nagashima, T. Yamazaki, J. Nakamura, Electrochem. Solid-State Lett. 2006, 9, A160.

[22] C. Wang, M. Waje, X. Wang, J. M. Tang, R. C. Haddon, Y. S. Yan, Nano Lett. 2004, 4, 345

[23] M. M. Waje, X. Wang, W. Z. Li, Y. S. Yan, Nanotechnology 2005, 16, S395.

[24] K. Hata, D. N. Futaba, K. Mizuno, T. Namai, M. Yumura, S. Iijima, Science 2004, 306, 1362

[25] J. M. Tang, K. Jensen, W. Li, M. Waje, P. Larsen, P. Ramesh, M. E. Itkis, Y. Yan, R. C. Haddon, Aust. J. Chem. 2007, 60, 528.

[26] S. C. Glotzer, M. J. Solomon, N. A. Kotov, Aiche J. 2004, 50, 2978.

[27] P. T. Hammond, Adv. Mater. 2004, 16, 1271.

[28] K. J. Loh, J. Kim, J. P. Lynch, N. W. S. Kam, N. A. Kotov, Smart Mater. Struct. 2007, 16, 429.

[29] N. A. Kotov, MRS Bull. 2001, 26, 992.

[30] N. A. Kotov, I. Dekany, J. H. Fendler, J. Phys. Chem. 1995, 99 13065 .
[31] P. Podsiadlo, A. K. Kaushik, E. M. Arruda, A. M. Waas, B. S. Shim, J. D. Xu, H. Nandivada, B. G. Pumplin, J. Lahann, A. Ramamoorthy, N. A. Kotov, Science 2007, 318, 80.

[32] G. Decher, Science 1997, 277, 1232.

[33] Y. Lvov, G. Decher, H. Möhwald, Langmuir 1993, 9, 481.

[34] T. Cassagneau, J. H. Fendler, J. Phys. Chem. B 1999, 103, 1789.

[35] Z. W. Chen, L. B. Xu, W. Z. Li, M. Waje, Y. S. Yan, Nanotechnology 2006, 17,5254 .

[36] M. Olek, J. Ostrander, S. Jurga, H. Möhwald, N. Kotov, K. Kempa, M. Giersig, Nano Lett. 2004, 4, 1889.

[37] T. R. Farhat, P. T. Hammond, Adv. Funct. Mater. 2005, 15, 945.

[38] M. Michel, A. Taylor, R. Sekol, P. Podsiadlo, P. Ho, N. Kotov, L. Thompson, Adv. Mater. 2007, 19, 3859.

[39] Y. Wang, X. Xu, Z. Q. Tian, Y. Zong, H. M. Cheng, C. J. Lin, Chem Eur. J. 2006, 12, 2542.

[40] E. Reverchon, R. Adami, J. Supercrit. Fluids 2006, 37, 1.

[41] Z. Y. Sun, L. Fu, Z. M. Liu, B. X. Han, Y. Q. Liu, J. M. Du, J. Nanosci. Nanotechnol. 2006, 6, 691.

[42] X. R. Ye, Y. H. Lin, C. M. Wang, M. H. Engelhard, Y. Wang, C. M Wai, J. Mater. Chem. 2004, 14, 908.

[43] C. H. Yen, X. L. Cui, H. B. Pan, S. F. Wang, Y. H. Lin, C. M. Wai, J. Nanosci. Nanotechnol. 2005, 5, 1852.

[44] Y. H. Lin, X. L. Cui, C. Yen, C. M. Wai, J. Phys. Chem. B 2005, 109 14410.

[45] A. D. Taylor, R. C. Sekol, J. M. Kizuka, S. D’Cunha, C. M. Comisar, J. Catal., in press.

[46] T. D. Gierke, G. E. Munn, F. C. Wilson, J. Polym. Sci. Part B 1981, 19 1687.

[47] F. Knowledge, Fuel Cells Durability, Stationary, Automotive, Portable: Furthering Science through Information, Knowledge Press, Brookline, MA 2006.

[48] J. H. Cheung, W. B. Stockton, M. F. Rubner, Macromolecules 1997, 30, 2712.

[49] T. R. Farhat, P. T. Hammond, Adv. Funct. Mater. 2006, 16, 433.

[50] R. Bashyam, P. Zelenay, Nature 2006, 443, 63.

[51] A. A. Mamedov, N. A. Kotov, M. Prato, D. M. Guldi, J. P. Wicksted, A. Hirsch, Nat. Mater. 2002, 1, 190.

[52] B. S. Shim, Z. Y. Tang, M. P. Morabito, A. Agarwal, H. P. Hong, N. A. Kotov, Chem. Mater. 2007, 19, 5467.

[53] K. D. Kreuer, Chem. Mater. 1996, 8, 610.

[54] M. Eikerling, A. A. Kornyshev, A. M. Kuznetsov, J. Ulstrup, S Walbran, J. Phys. Chem. B 2001, 105, 3646.

[55] J. Kerres, A. Ullrich, F. Meier, T. Haring, Solid State Ionics 1999, 125 243

[56] B. S. Shim, P. Podsiadlo, D. G. Lilly, A. Agarwal, J. Leet, Z. Tang, S Ho, P. Ingle, D. Paterson, W. Lu, N. A. Kotov, Nano Lett. 2007, 7, 3266.

[57] D. L. Elbert, C. B. Herbert, J. A. Hubbell, Langmuir 1999, 15, 5355.

[58] C. Picart, P. Lavalle, P. Hubert, F. J. G. Cuisinier, G. Decher, P. Schaaf, J. C. Voegel, Langmuir 2001, 17, 7414.

[59] B. S. Shim, N. A. Kotov, Langmuir 2005, 21, 9381. 